CLINICAL ETHICS

\title{
On judgment and judgmentalism: how counselling can make people better
}

S Gibson

J Med Ethics 2005;31:575-577. doi: 10.1136/jme.2004.011387

Counsellors, like other members of the caring professions, are required to practise within an ethical framework, at least in so far as they seek professional accreditation. As such, the counsellor is called upon to exercise her moral agency. In most professional contexts this requirement is, in itself, unproblematic. It

Correspondence to: S Gibson, Division of Religion and Philosophy, St Martin's College, Lancaster, LAl 3JD s.gibson@ucsm.ac.uk

Received 3 December 2004 Accepted for publication 7 December 2004 has been suggested, however, that counselling practice does present a problem in this respect, in so far as the counsellor is expected to take a non-judgemental stance and an attitude of "unconditional positive regard" toward the client. If, as might appear to be the case, this stance and attitude are at odds with the making of moral judgments, the possibility of an adequate ethics of counselling is called into question. This paper explores the nature and extent of the problem suggesting that, understood in a Kantian context, non-judgmentalism can be seen to be at odds with neither the moral agency of the counsellor nor that of the client. Instead, it is argued, the relationship between the non-judgmental counsellor and her client is a fundamentally moral relationship, based on respect for the client's unconditional worth as a moral agent.

C ounsellors are required to practise within an ethical framework, at least in so far as they seek professional accreditation. ${ }^{1}$ At the same time, some influential models of counselling seem to eschew the making of moral judgments in that they specify a "non-judgmental" stance on the part of the counsellor. This has raised the question whether an adequate ethics of counselling is possible. ${ }^{2}$ In this paper it is argued that, understood in a Kantian context, nonjudgmentalism is at odds with the moral agency of neither the counsellor nor the client. Rather, the relationship between the non-judgmental counsellor and her client is a fundamentally moral relationship, based on respect for the client's worth as a moral agent.

\section{JUDGMENT AND VALUE IN ETHICS AND COUNSELLING}

Following Blum, moral judgment can be understood as bridging the divide between moral rules or principles on the one hand and particular situations on the other. More specifically, judgment is employed in recognising that a situation has morally significant features, and what those features are. It is used in selecting the rule or principle applicable to the situation and in deciding which acts count as exemplifying and which act best exemplifies the chosen principle. It is further employed in deciding whether one should act (whether there is anything one can or ought to do) and finally, in determining how to perform the chosen moral action. ${ }^{3}$

For the counsellor, judgment is similarly employed in deciding what interventions to make, and when and how to make them. This in turn is informed by the principles of counselling to which the practitioner adheres: as with moral judgment, judgment is used in counselling to bridge the gap between principle and practice. ${ }^{4}$

What are those principles? While ethics is concerned with the minimisation of unnecessary suffering and the promotion of human flourishing, among the fundamental values of counselling are a commitment to the alleviation of distress and suffering, the promotion of personal effectiveness, and the enhancement of personal relationships. ${ }^{1}$ The aims and values of ethics and counselling, then, appear to be broadly similar. ${ }^{5}$ Thus, in so far as there is a conflict in the relationship between ethics and counselling it does not arise out of a clash between the values of counselling and those of morality. Rather, it is argued, the conflict is between what it means to adhere to those values and one of the specific requirements of counselling practice.

\section{THE NON-JUDGMENTAL COUNSELLOR}

Although by no means restricted to this model, nonjudgmentalism is most closely associated with person centred counselling. ${ }^{6}$ For Carl Rogers non-judgmentalism is exemplified in the attitude of "unconditional positive regard", one of the "core conditions" of person centred counselling, which, if provided by the therapist, is said almost inevitably to result in growth in the client. ${ }^{7}$ Notwithstanding the counsellor's use of judgment, one can see why non-judgmentalism appears to be at odds with moral judgment and hence with the counsellor's exercise of moral agency. It is precisely in terms of evaluating the client, their beliefs, attitudes or behaviour, that the concept is to be understood. According to Rogers, unconditional positive regard "is at the opposite pole from a selective evaluating attitude-'you are bad in these ways, good in those $^{\prime \prime \prime}$ (Rogers, ${ }^{7}$ p 225). For Thorne, "[g]enuine acceptance is totally unaffected by differences of background or belief system between client and therapist, for it is in no way dependent on moral, ethical or social criteria" (Thorne, ${ }^{4} \mathrm{p}$ 134).

So what becomes of the non-judgmental counsellor as moral agent? If the practice of counselling presupposes adherence to a system of values, ${ }^{2}$ and if registration as a counsellor requires adherence to a framework of distinctly ethical values, what happens to those values in the context of the relationship between counsellor and client? The counsellor cannot leave her values outside of the counselling room since she needs them to inform her practice and to ensure that she is working within the requisite ethical parameters. At the same time it appears that she must refrain from judging the client in the light of those values.

One way around this difficulty is to appeal to an account of the status of moral values such that they appropriately inform the behaviour of the person holding them, but are inappropriately applied when used to judge others. Thus the counsellor's values are present in the counselling relationship, accessible to the counsellor in informing her own behaviour, but reduced to subjective opinion or attitude, no 
more-and probably in the context of counselling less-valid than the subjective opinion and attitude of the client.

While an appeal to the subjective status of values might suggest a coherent account of what it is to be a nonjudgmental moral agent, for Johnston it is this tendency toward subjectivism, or as he terms it, relativism, (Johnston, ${ }^{2}$ p 489) which is at the heart of the problem. Put simply, subjectivism is not an attractive position for anyone taking seriously the question "What is the right thing to do?" To use Johnston's example, one generally wants to be able to say that there is something wrong with cruelty toward children, and that the wrongness does not depend upon how one feels about cruelty toward children. Further, it is not just that there are cases in which one wants to be able to make a moral judgment regarding the behaviour or character of another. If subjectivism is the only account of the status of moral judgment with which counselling is compatible, then there are no moral grounds on which to require the counsellor's adherence to a code of professional ethics. The only commitment binding on all non-judgmental counsellors would be the commitment to subjectivism. Beyond this, a code of ethics would be valid only in so far as it happened to fit with the subjective moral values of the particular counsellor.

\section{THE "THERAPEUTIC SENSIBILITY"}

Johnston argues that a commitment to the values of person centred counselling is incompatible with a commitment to moral relativism or subjectivism. Thus he suggests that what is required is a revision of the notions of what it is to be nonjudgmental, such that the individual client is no longer regarded as "sovereign" in the generation of his own values. ${ }^{2}$ It is unclear that one cannot be committed both to subjectivism and to the values of person centred counselling, since it is possible that the values of person centred counselling just are those of subjectivism. This does not, however, answer the problem of subjectivism itself, which, for some critics, far from being at odds with the values of counselling is in fact inherent in a broader "therapeutic" ethos. On this account, the values of counselling are not so much in tension with the non-judgmental stance of the counsellor but provide its justification.

Phillips distinguishes between "morality" on the one hand and the "therapeutic sensibility" on the other. In the contemporary world religion is no longer experienced as a source of authoritative rules of conduct, and therefore individuals are left with two options in deciding how to act. They can choose to act according to considerations of morality, of what is good or right in itself, or they can choose to act according to what they think will best satisfy their own desires. ${ }^{8}$ Regrettably, Phillips believes, most of us opt for desire satisfaction, and this he sees as a function of the prevailing "therapeutic sensibility", concerned as it is with the pursuit of "authenticity", with acting according to one's inner impulses rather than according to artificially imposed social constraints. Thus the therapeutic life is a rejection of the moral life; it is the "renunciation of renunciation" (Phillips, ${ }^{8}$ p 26). And it is not just that people do in fact tend to pursue the authentic rather than the moral life: authenticity has come to replace morality as the standard of human adequacy. Thus the "self is to be judged not by adherence to moral standards or by the possession of moral virtues, but by the degree of allegiance to one's internal feelings and impulses" (Phillips, ${ }^{8}$ p 24). The successful person just is the authentic person.

For Phillips, the therapeutic sensibility is both product and perpetrator of a subjective account of moral value. ${ }^{9}$ Once we discover that we cannot appeal to the commands of God in order to secure an objective grounding for our moral principles, we must either seek an alternative objective account of morality, or abandon the search altogether. To pursue authenticity is to opt for the latter. While the therapeutic sensibility is a successor to religious and moral thinking, replacing the dictates of external authority with the dictates of one's own inner desires, the "morality" that it proposes is not morality at all, since it is concerned only with prudence. Thus it is said that "People whose actions are regulated by prudence, reject the idea that there are moral virtues, obligations, or other requirements which are independent of prudence...Since such persons view social relationships as reducible to individual desires or to a calculation of means and ends, moral discourse does not even exist for them. Moral judgments, they believe, are reducible to questions of the most subjective personal taste. ('If it feels good, do it')" (Phillips, ${ }^{8}$ p 30).

If the therapeutic goal is to enable the client to get in touch with and then act on his own feelings, then the therapist has no business issuing the client with moral guidance. The nonjudgmental, non-directive stance is requisite. If, however, the result is a society in which people are encouraged to pursue their own goals, free from concern for others, then the status of counselling as a moral practice is seriously undermined. It is not just that the counsellor is debarred from passing moral judgment; on this account of living well, morality all but disappears. There are no moral judgments to be made.

\section{ROGERS ON DOING WHAT FEELS RIGHT}

Following Kierkegaard, for Rogers "the deepest responsibility of man" is "to will to be that self which one truly is". ${ }^{10}$ In order to be that self which one truly is, one must abandon the false self, made up of the masks, facades or roles that one hides behind in order to face the world. This means moving away from notions of what one ought to do, away from meeting the expectations of, or pleasing, others and toward identifying and satisfying one's own needs (Rogers, ${ }^{10}$ pp 168$70)$. The self that emerges is increasingly aware of his own feelings and attitudes, recognising "that the only question which matters is, "Am I living in a way which is deeply satisfying to me, and which truly expresses me?" (Rogers, ${ }^{10} \mathrm{p}$ 119). Rogers emphasises the way in which clients come to replace reliance upon guiding principles with "doing what feels right". "Doing what feels right", it turns out, is the best way for the client to discern the course of action most likely to satisfy as many of his needs as possible (Rogers, ${ }^{10} \mathrm{p} \mathrm{190).}$

While it is possible to read Rogers's account of personal growth as the exemplification of the "therapeutic sensibility", a closer reading suggests an alternative understanding. In one paper, Rogers himself grapples with "the problem of values". Like Phillips, Rogers notes that "world culture, in all its aspects, seems increasingly scientific and relativistic, and the rigid, absolute views on values which come to us from the past appear anachronistic...It is no longer possible, as it was in the not too distant historical past, to settle comfortably into the value system of one's forebears or one's community and live out one's life without ever examining the nature and the assumptions of that system" (Rogers, ${ }^{7}$ pp 168-9). Far from retreating into subjectivism, however, Rogers suggests that person centred counselling can assist in the search for universal values. What Rogers observes is that when people are free to choose their own values, there seems to be a commonality in the values they select. Further, the tendency is for individuals to value that which contributes not only to their own survival and development but also to the survival and development of others.

Rogers observes this direction rather than attempting to explain it. It is my contention that an account of the relationship between moral agency and the self governance that the non-judgmental counsellor seeks to promote can furnish just such an explanation. 


\section{MORAL AGENCY AND SELF GOVERNANCE}

For Rogers, one outcome of successful counselling is the move toward autonomy or self direction (Rogers, ${ }^{10} \mathrm{pp} 170-1$ ). For Kant, autonomy is at the heart of moral agency. Indeed, it is precisely in so far as one acts autonomously that one acts morally: acting on the basis of self rule and acting according to the moral law are one and the same. If autonomy and moral agency are one and the same, it follows that where one acts heteronomously - that is, according to the dictates of anything other than one's own freedom of will-one fails to act as a moral agent. Another way to put this is to say that to act heteronomously is to act on the basis of contingency. It is only when one acts autonomously that one enacts the universality or objective necessity that is the defining feature of the moral law. ${ }^{11}$

Might Rogers's account of personal growth be understood as an account of moral growth, with the client moving from heteronomy to autonomy? If so, Johnston's objection that there is an inconsistency between a commitment to individual sovereignty and a commitment to objective moral value is misplaced. For Kant, it is precisely in so far as the individual chooses through the exercise of autonomy which values to live by that those values are moral values, properly understood; that is, understood as objective rather than contingent values. Certainly, the movement Rogers charts is a move away from one kind of contingency or heteronomy, since the "oughts" that are cast off by the client are in the form of the hypothetical imperatives that Kant rejects as a basis for morality (Kant, ${ }^{11}$ p 88). To use one of Rogers's examples, where the client rejects the imperative "You ought to be good", what he is rejecting is an imperative along the lines of "You ought to be good if you want to please your parents": the force of the imperative is contingent upon his wanting to please his parents. Thus when Rogers says of his clients that "They do not wish to be what they 'ought' to be, whether that imperative is set by parents, or by culture...They do not wish to mould themselves and their behaviour into a form which would be merely pleasing to others. They do not, in other words, choose... anything which is imposed, anything which is defined from without" (Rogers, ${ }^{10}$ p 170), he is not charting the rejection of an objective morality, but, in Kantian terms, of its antithesis.

As the client moves away from hypothetical "oughts", he moves toward self direction and autonomy. It is not clear, however, that the client is autonomous and self governing in the Kantian sense. After all, for Kant, rule by one's own desires is just as much heteronomy as rule by the desires of another. Thus Sullivan argues that while Rogers's conception of autonomy shares some features of the Kantian conception, in so far as it is understood entirely in terms of the freedom to identify and meet one's own needs, it does not capture the essential component. For Kant autonomy is understood as a self imposed limit to individual freedom: the rationally chosen objective end of the universal moral law limits the subjective ends that are individual needs and desires (Kant, ${ }^{11}$ pp 69-70). ${ }^{12}$

Yet Rogers's claim is that "when the human being is inwardly free to choose whatever he deeply values, he tends to value those objects, experiences, and goals which make for his own survival, growth, and development, and for the survival and development of others" (emphasis added) (Rogers, p 183). Why should the individual, as he tends toward self direction be concerned with the survival and development of others? The answer lies in the recognition that we are fundamentally social beings. For Rogers, among our deepest needs are our social needs, such as our needs for affiliation, communication, and companionship (Rogers, ${ }^{10}$ pp 194-5). In short, we need to be able to get along with others, both in the sense of interpersonal cooperation and in the sense of forming interpersonal bonds. What Kant explicitly and Rogers implicitly comprehends (or perhaps more accurately, what his clients comprehend) is that we achieve this by acting only on those values that are shareable by other similarly finite, rational, social beings.

Rogers's empirical observation that when people become self governing they tend to select universal-and universalisable-values bears out Kant's conceptual analysis of the relationship between self governance and the moral law. While it would be disingenuous to claim that there are no significant differences between Rogers's fully functioning person and Kant's rationally autonomous moral agent, it appears that they have far more in common with each other than either has with the model of prudential personhood inherent in the therapeutic sensibility. Certainly, it is not the case that, as Johnston suggests, to regard the individual as the locus of evaluation is to commit oneself to relativism. On the contrary, individual sovereignty, appropriately understood, is one of the keys to the generation of universal values and a necessary condition for moral agency.

\section{CONCLUSION}

While the non-judgmental counsellor may not hand out moral directives to the client, the relationship between counsellor and client has a distinctly and robustly moral foundation. Non-judgmentalism consists in neither the abdication of moral responsibility on the part of the counsellor, nor the encouragement of amorality in the client. Rather, the nonjudgmental counsellor recognises and works to develop in the client the capacity for self directed moral agency. As such, the argument for non-judgmental, unconditional positive regard is itself a moral argument. While non-judgmentalism consists in the recognition of and respect for the client's moral agency, unconditional positive regard is founded on respect for the client's worth as a moral agent. ${ }^{13}$ In the Groundworkof the Metaphysic of Morals Kant concludes that humanity alone, by virtue of its rationality and hence its moral agency, has absolute, or unconditional worth (Kant, ${ }^{11}$ pp 64-6). The client, then, has unconditional worth by virtue of his moral agency and it is by virtue of his moral agency that he is worthy of the counsellor's unconditional positive regard.

\section{REFERENCES}

1 British Association for Counselling and Psychotherapy. Ethical framework for good practice in counselling and psychotherapy http://www.bacp.co.uk/ printable/ethical_framework.html (accessed 4 Mar 2004)

2 Johnston M. On becoming non-judgmental: some difficulties for an ethics of counselling. J Med Ethics 1999;25:487-90.

3 Blum LA. Moral perception and particularity. Cambridge: Cambridge University Press, 1994:31.

4 Thorne B. Person-centred therapy. In: Dryden W, ed. Handbook of individual therapy. London: Sage, 1996:133ff.

5 Gallagher A. Do virtues have a role in the practice of counselling? In: Robb M, Barrett S, Kamaromy C, et al, eds. Communication, relationships and care: a reader. London: Routledge, 2004

6 Casemore $R$. Does a counsellor have a responsibility to challenge a client's prejudices? In: Jones C, Shillito-Clarke C, Syme G, et al, eds. Questions of ethics in counselling and therapy. Buckingham: Open University Press, 2000:56.

7 Rogers C. A client centred/person centred approach to therapy. In: Kirschenbaum H, Henderson VL, eds. The Carl Rogers reader. London: Constable, 1990:136.

8 Phillips D. Authenticity and morality. In: Kruschtwitz RB, Roberts RC, eds. The virtues. Belmont: Wadsworth, 1987:29.

9 Macintyre A. After virtue. London: Duckworth, 1985.

10 Rogers C. On becoming a person: a therapist's view of psychotherapy. London: Constable, 1999:110.

11 Kant I. Groundwork of the metaphysic of morals. New York: Harper, 1964;87-96, 97-8.

12 Sullivan R. Immanuel Kant's moral theory. Cambridge: Cambridge University Press, 1989:46-7

13 Purton C. Unconditional positive regard and its spiritual implications. In: Thorne B, Lambers C, eds. Person centred therapy: a European perspective. London: Sage, 1998. 